\title{
KARAKTERISTIK PERILAKU DAN PROFIL HIPERTENSI PADA PASIEN PEROKOK YANG BEROBAT DI PUSKESMAS BULILI KOTA PALU TAHUN 2019
}

\author{
Muh Yaqub Basri ${ }^{1}$, Nita Damayanti ${ }^{2}$, Muh Ali Hi Palanro ${ }^{3}$ \\ ${ }^{1}$ Program Studi Pendidikan Dokter, Fakultas Kedokteran, Universitas Alkhairaat, Jl. Diponegoro Palu \\ 94221, Sulawesi Tengah, Indonesia \\ "Corresponding author: Telp: +62 82292060496, email: hasanyaqub99@ gmail.com
}

\begin{abstract}
ABSTRAK
Hipertensi menjadi masalah yang besar dan serius di seluruh dunia yang menjangkiti hampir 9,4 miliyar orang. Sekitar $24 \%$ pria dan $20,5 \%$ wanita di seluruh dunia mengidap hipertensi, hal ini berkaitan erat dengan gaya hidup seperti: merokok, diet tinggi lemak dan garam, aktivitas fisik, dll. Faktor risiko tersebut masih sering dijumpai di negara berkembang seperti Indonesia khususnya di kota Palu. Tujuan penelitian ini adalah untuk Mengetahui karakteristik, perilaku, dan profil hipertensi pasien perokok yang berobat di Puskesmas Bulili Palu tahun 2019. Metode penelitian ini adalah deskriptif dengan design Cross sectional study terhadap 80 pasien dewasa. Pengumpulan data dengan pengukuran tekanan darah dan wawancara menggunakan kuesioner. Hasil penelitian ditemukan kebanyakan perokok yang berobat di Puskesmas Bulili Palu merokok 11-20 batang perhari (perokok sedang) yaitu 52 orang (65\%). Perokok yang berobat di Puskesmas Bulili Palu kebanyakan sudah merokok lebih dari 10 tahun (perokok lama) yaitu 46 orang $(57,5 \%)$, perilaku diet tinggi lemak perokok yang berobat di Puskesmas Bulili Palu kebanyakan termasuk dalam kategori sedang yaitu 40 orang (50\%), sementara perilaku diet tinggi garam penduduk yang berobat di Puskesmas Bulili Palu kebanyakan terkategori sedang yaitu 53 orang $(66,3 \%)$, serta perilaku aktivitas fisik perokok yang berobat di Puskesmas Bulili Palu kebanyakan terkategori ringan yaitu 53 orang (66,3\%). Selain itu, kebanyakan perokok yang berobat di Puskesmas Bulili Palu menderita hipertensi derajat 1 yaitu 56 orang $(70 \%)$ sedangkan perokok yang menderita hipertensi derajat 2 yaitu 24 orang $(30 \%)$. Sebagai kesimpulan banyak perokok yang berobat di Puskesmas Bulili Palu tahun 2019 berusia 56-65 tahun masih memiliki kebiasaan merokok yang tergolong sedang sampai berat dengan gaya hidup tergolong buruk.
\end{abstract}

Kata Kunci: merokok, profil hipertensi

ABSTRACT

Hypertension is a big and serious problem throughout the world, affecting almost 9.4 billion people. About $24 \%$ of men and $20.5 \%$ of women worldwide suffer from hypertension, this is closely related to lifestyles such as: smoking, a diet high in fat and salt, physical activity, etc. These risk factors are still often found in developing countries such as Indonesia, especially in the city of Palu. The purpose of this study was to determine the characteristics, behavior, and hypertension profile of smokers who seek treatment at the Public Health Center of Bulili of Palu in 2019. The method of this study was descriptive with a cross sectional study design of 80 adult patients. Data collection by blood pressure measurement and interview using a questionnaire. The results of the study found that most smokers who seek treatment at the Public Health Center of Bulili smoked 11-20 cigarettes per day (moderate smokers), namely 52 people (65\%). Smokers who seek treatment at the Public Health Center of Bulili have mostly smoked more than 10 years (old smokers), namely 46 people (57.5\%), high-fat dietary behavior of smokers who seek treatment at the Public Health Center of Bulili are mostly included in the moderate category of 40 people $(50 \%)$ ), while the high-salt dietary behavior of the people who seek treatment at the Public Health Center of Bulili is mostly categorized as moderate, namely 53 people (66.3\%), and the physical activity behavior of smokers who seek treatment at the Public Health Center of Bulili is mostly mild, namely 53 people (66.3\%). In addition, most smokers who seek treatment 
at the Public Health Center of Bulili suffer from first-degree hypertension, namely 56 people (70\%) while smokers who suffer from second-degree hypertension, namely 24 people (30\%).

Keywords: smoking, hypertension profile

\section{PENDAHULUAN}

Salah satu masalah kesehatan masyarakat yang sedang dihadapi saat ini dalam pembangunan kesehatan di Indonesia adalah beban ganda penyakit, yaitu disatu sisi masih ada penyakit infeksi yang harus ditangani dan dilain sisi semakin meningkatnya penyakit tidak menular. Proporsi angka kematian penyakit tidak menular menigkat dari 41,7 \% pada tahun 1995 menjadi 59,5\% pada tahun $2007{ }^{1}$

Hipertensi menjadi masalah yang besar dan serius di seluruh dunia karena hampir 9,4 milyar orang meninggal setiap tahun disebabkan oleh penyakit tersebut. Disamping karena prevalensinya yang tinggi dan terus meningkat dari tahun ke tahun, hipertensi juga merupakan penyebab utama timbulnya penyakit kardiovaskuler seperti serangan jantung, gagal jantung, dan stroke. Tekanan darah tinggi (Hipertensi) menjangkiti sekitar $24 \%$ pria dan $20,5 \%$ wanita di seluruh dunia. ${ }^{2,3}$

Hipertensi adalah keadaan tekanan darah sistolik lebih dari $140 \mathrm{mmHg}$ dan tekanan darah diastolik lebih dari $90 \mathrm{mmHg} .{ }^{5,6}$

Pada tahun 2017 mereka yang terdiagnosa hipertensi pada orang dewasa di Amerika Serikat mencapai $46 \%$ lebih besar dari angka kejadian hipertensi sebelumnya yang mencapai $32 \%$. Berdasarkan penelitian terkait dengan hubungan antara faktor risiko hipertensi dan prevelensi hipertensi pada penduduk kota Varanasi, India pada 640 subjek penelitian yang berusia 25-64 tahun didapatkan hasil prevalensi hipertensi adalah 32,9\% (laki-laki: 40,9\%, perempuan: 26,0\%). Kemungkinan lebih tinggi menjadi hipertensi ditemukan pada subjek pria, kelompok usia tertua, subjek menikah, subjek status sosial ekonomi atas, subjek buta huruf, dan subjek yang sudah pensiun. Konsumsi tembakau dan alkohol, kelebihan berat badan, obesitas, dan obesitas perut juga dikaitkan dengan hipertensi. ${ }^{7,8}$

Prevelensi hipertensi di Indonesia yang di dapat melalui pengukuran pada umur $\geq 18$ tahun sebesar 25,8 \%, tertinggi di Bangka Belitung (30,9\%). Di sulawesi tengah sendiri $28,7 \%$. Di Sulawesi Tengah, angka kejadian hipertensi cenderung meningkat dari tahun 2014 sebesar 69.521 jiwa menjadi 96.213 jiwa pada tahun 2016, sementara itu pravalensi hipertensi di kota Palu tahun 2016 sebanyak 1503 kasus yang kemudian meningkat pada pada tahun 2017 sebesar 9400 kasus. Pada penelusuran data yang dilakukan di Puskesmas Bulili Palu tahun 2017 hipertensi menjadi penyakit peringkat ke-6 dengan jumlah penderita sebanyak 364 orang dan menjadi peringkat ke-3 dalam 10 penyakit terbanyak tahun 2018 sebanyak 1358 kasus. ${ }^{4,9,10,11}$

Karena tingginya prevelensi hipertensi di dunia membuat banyak peneliti melakukan penelitian terkait dengan faktor risiko hipertensi dalam hal gaya hidup seperti : merokok, makanan tinggi lemak dan garam, kurangnya aktivitas berolahraga, serta ketidak patuhan minum obat antihipertensi sebagai pemicu timbulnya berbagai komplikasi penyakit kardiovaskuler. ${ }^{12,13}$

Indonesia menempati urutan pertama jumlah perokok terbanyak di dunia dengan angka kejadian sebesar $67 \%$, dan untuk kota Palu sendiri menjadi salah satu kota dengan perokok aktif terbanyak di Sulawesi Tengah dengan 2062 jiwa. ${ }^{9,14}$

\section{METODOLOGI}

Jenis dan Rencana Penelitian

Penelitian ini merupakan penelitian kuantitatif yang menggunakan desain deskriptif dengan pendekatan cross-sectional yaitu penelitian yang menggambarkan karakteristik perilaku dan profil hipertensi pada pasien perokok yang berobat di PKM Bulili Kota Palu tahun 2019.

\section{Waktu dan Tempat Penelitian}

1. Waktu Penelitian

Penelitian dilaksanakan pada bulan Juli hingga september 2019.

2. Tempat Penelitian 
Penelitian ini dilakukan di Puskesmas Bulili kota Palu. Pemilihan lokasi berdasarkan atas pertimbangan bahwa belum pernah dilakukannya penelitian terkait dengan karakteristik perilaku dan profil hipertensi pada pasien perokok yang datang berobat di Puskesmas Bulili kota Palu.

\section{Populasi dan Sampel Penelitian serta Teknik} Pengambilan Sample

1. Populasi dan Sampel Penelitian

Populasi dalam penelitian ini adalah penduduk berusia $\geq 18$ tahun yang datang berobat di Puskesmas Bulili kota Palu, sedangkan sampel penelitian adalah sebagian yang diambil dari keseluruhan objek penelitian yang dianggap mewakili seluruh populasi dengan terpenuhinya kriteria inklusi.

\section{Teknik Pengambilan Sampel}

Teknik pengambilan sampel yang digunakan pada penelitian ini adalah dengan menggunakan metode consecutive sampling yaitu mengumpulkan semua sampel yang memenuhi kriteria penelitian sampai sampel terpenuhi.

\section{Besar Sampel}

Penentuan besar sampel dari penelitian yang bersifat deskriptif kategorik membutuhkan perhitungan berdasarkan rumus Teknik Slovin.

\section{Analisa Data}

Analisa data yang digunakan adalah untuk melihat karakteristik perilaku pada pasien hipertensi perokok berdasarkan kebiasaan merokok, diet tinggi lemak, diet tinggi garam, aktivitas fisik serta profil hipertensi menggunakan perangkat lunak komputer program SPSS (Statistical Product and Service Solution) 24 dan Microsof Excell.

\section{HASIL DAN PEMBAHASAN}

HASIL

Penelitian ini dilakukan di Puskesmas Bulili Kota Palu tahun 2019 dengan subjek pada penelitian ini diambil dari Populasi (Penduduk usia $\geq 18$ tahun) yang berobat di Puskesmas Bulili Palu dan memenuhi kriteria sampel sebanyak 80 orang. Pengumpulan data penelitian ini dilakukan dengan cara melakukan pengukuran tekanan darah, pengisian kuesioner kebiasaan merokok, kebiasaan konsumsi makanan tinggi lemak dan garam, serta aktivitas fisik selama seminggu terakhir. Adapun data yang diperoleh terdiri dari tekanan darah sistolik dan diastolik, kebiasaan merokok digolongkan menjadi ringan, sedang dan berat, diet tinggi lemak dan diet tinggi garam yang digolongkan menjadi ringan, sedang dan tinggi.

1. Karakteristik demografi sampel penelitian menurut umur dan jenis kelamin penduduk (usia $\geq 18$ tahun) yang berobat di Puskesmas Bulili Palu tahun 2019.

Tabel 1. dibawah menunjukkan karakteristik dari 80 sampel penduduk berusia $\geq 18$ tahun di Puskesmas Bulili palu:

\begin{tabular}{ccc}
\hline \multicolumn{3}{c}{ Karakteristik Sampel Berdasarkan Usia } \\
\hline Usia & f & $(\%)$ \\
\hline Remaja Akhir (17-25 tahun) & 4 & 5,0 \\
Dewasa Awal (26-35 tahun) & 10 & 12,5 \\
Dewasa Akhir (36-45 tahun) & 12 & 15,0 \\
Lansia Awal (46-55 tahun) & 21 & 26,3 \\
Lansia Akhir (56-65 tahun) & 28 & 35,0 \\
Manula (>65 tahun) & 5 & 6,3 \\
\hline Total & 80 & 100 \\
\hline
\end{tabular}

Sumber: data Prımer (2U1Y)

Sementara itu dari penelitian ini juga didapati hasil analisis antara usia responden penelitian dengan profil hipertensi yang diderita dalam tabel 2 .

Adapun karakteristik sampel berdasarkan jenis kelamin dicantumkan dalam tabel 3 berikut ini:

Tabel 3. Karakteristik sampel berdasarkan jenis kelamin

\begin{tabular}{ccc}
\hline \multicolumn{3}{c}{ Karakteristik Sampel Berdasarkan } \\
Jenis Kelamin \\
\hline Jenis Kelamin & $\mathrm{f}$ & $(\%)$ \\
\hline Laki-laki & 47 & 58,8 \\
Perempuan & 33 & 41,3 \\
\hline Total & 80 & 100
\end{tabular}


Tabel 2. Analisis antara usia responden penelitian dengan profil hipertensi yang diderita

\begin{tabular}{cccc}
\hline \multirow{2}{*}{ Usia } & \multicolumn{2}{c}{ Profil Hipertensi } & \multirow{2}{*}{ Total } \\
\cline { 2 - 3 } & HT drj.1N $(\%)$ & HT drj. 2N $(\%)$ & \\
\hline Remaja Akhir & $4(7,1 \%)$ & $0(0 \%)$ & $4(5 \%)$ \\
\cline { 2 - 4 } Dewasa Awal & $10(17,9 \%)$ & $0(0 \%)$ & $10(12,5 \%)$ \\
\cline { 2 - 4 } Dewasa Akhir & $7(12,5 \%)$ & $5(20,8 \%)$ & $12(15 \%)$ \\
\cline { 2 - 3 } Lansia Awal & $12(21,4 \%)$ & $9(37,5 \%)$ & 21 \\
Lansia Akhir & & $(26,3 \%)$ \\
Manula & $22(39,3 \%)$ & $6(25 \%)$ & $28(35 \%)$ \\
\cline { 2 - 4 } & $1(1,8 \%)$ & $4(16,7 \%)$ & $5(6,3 \%)$ \\
Total & 56 & 24 & $80(100 \%)$ \\
\hline
\end{tabular}

Dari tabel diatas menunjukkan karakteristik sampel penelitian di Puskesmas Bulili Kota Palu tahun 2019 yang berjumlah 80 orang. Dari 80 sampel yang diteliti, diperoleh persentase sampel berusia 17-25 tahun (remaja akhir) sebanyak 4 orang (5\%), sampel berusia 26-35 tahun (dewasa awal) sebanyak 10 orang $(12,5 \%)$, sampel berusia 36-45 tahun (dewasa akhir) sebanyak 12 orang (15\%), berusia $46-55$ tahun (lansia awal) sebanyak 21 orang (26,3\%), berusia 56-65 tahun (lansia akhir) sebanyak 28 orang $(35 \%)$, dan sampel berusia $>65$ tahun (manula) sebanyak 5 orang $(6,3 \%)$. Berdasarkan tabel distribusi sampel menurut jenis kelamin digolongkan atas sampel dengan jenis kelamin laki-laki sebanyak 47 orang $(58,8 \%)$, sedangkan yang berjenis kelamin perempuan sebanyak 33 orang (41,3\%).

2. Distribusi karakteristik perilaku pada pasien perokok yang berobat di Puskesmas Bulili Kota Palu tahun 2019

Tabel 4. Distribusi karakteristik perilaku pada pasien perokok berdasarkan frekuensi merokok.

Distribusi Karakteristik Sampel Berdasarkan Frekuensi Merokok

\begin{tabular}{ccc}
\hline Frekuensi Merokok & $\mathrm{f}$ & $(\%)$ \\
\hline Perokok Ringan & 21 & 26,3 \\
Perokok Sedang & 52 & 65 \\
Perokok Berat & 7 & 8,8 \\
\hline Total & 80 & 100 \\
\hline
\end{tabular}

Dari tabel 4 diatas, didapati bahwa responden yang merokok antara $1-10$ batang perhari (perokok ringan) berjumlah 21 orang $(26,3 \%)$, responden yang merokok 11-20 batang perhari (perokok sedang) berjumlah 52 orang $(65 \%)$, dan responden yang merokok $>20$ batang perhari (perokok berat) berjumlah 7 orang $(8,8 \%)$.

Tabel 5. Distribusi karakteristik perilaku pada pasien perokok berdasarkan lama merokok

Distribusi Karakteristik Sampel

Berdasarkan Lama Merokok

\begin{tabular}{ccc}
\hline Lama Merokok & f & $(\%)$ \\
\hline Perokok Pemula & 7 & 8,8 \\
Perokok Menengah & 27 & 33,8 \\
Perokok Lama & 46 & 57,5 \\
\hline Total & 80 & 100
\end{tabular}

Dari tabel diatas didapati data terkait distribusi responden yang berobat di Puskesmas Bulili Palu tahun 2019 berdasarkan lama merokok. Adapun responden yang merokok $<5$ tahun (perokok pemula) berjumlah 7 orang $(8,8 \%)$, responden yang selama 5-10 tahun (perokok menengah) berjumlah 27 orang $(33,8 \%)$, sedangkan responden yang sudah merokok selama >10 (perokok lama) berjumlah 46 orang $(57,5 \%)$. 
3. Distribusi karakteristik perilaku pada pasien perokok berdasarkan diet tinggi lemak yang berobat di Puskesmas Bulili Kota Palu tahun 2019

Tabel 6. Karakteristik sampel berdasarkan diet tinggi lemak

Distribusi Karakteristik Sampel Berdasarkan Diet Tinggi Lemak

\begin{tabular}{ccc}
\hline Diet Tinggi Lemak & $\mathrm{f}$ & $(\%)$ \\
\hline Ringan & 21 & 26,3 \\
Sedang & 40 & 50 \\
Berat & 19 & 23,8 \\
Sangat Berat & 0 & 0,0 \\
\hline Total & 80 & 100
\end{tabular}

Dari tabel 6 tersebut dapat diketahui responden dengan diet lemak tinggi yang tergolong katerogi ringan (1-2 kali perminggu) berjumlah 21 orang $(26,3 \%)$, responden dengan kategori sedang (3-6 kali perminggu) berjumlah 40 orang $(50 \%)$, dan responden dengan kategori berat (7 kali perminggu) berjumlah 19 orang $(23,8 \%)$, sementara responden dengan diet tinggi lemak kategorik sangat berat (lebih dari 1 kali dalam sehari) tidak ada.

4. Distribusi karakteristik perilaku pasien perokok berdasarkan diet tinggi garam yang berobat di Puskesmas Bulili Kota Palu tahun 2019

Tabel 7. Karakteristik sampel berdasarkan diet tinggi garam.

\begin{tabular}{ccc}
\hline \multicolumn{3}{c}{ Distribusi Karakteristik Sampel } \\
Berdasarkan Diet Tinggi Garam \\
\hline Diet Tinggi Garam & $\mathrm{f}$ & $(\%)$ \\
\hline Ringan & 16 & 20 \\
Sedang & 53 & 66,3 \\
Berat & 9 & 11,3 \\
Sangat Berat & 2 & 2,5 \\
\hline Total & 80 & 100 \\
\hline
\end{tabular}

Dari tabel diatas dapat diketahui bahwa responden dengan diet tinggi garam kategori ringan (1-2 kali perminggu) berjumlah 16 orang $(20 \%)$, responden dengan kateori sedang (3-6 kali perminggu) berjumlah 53 orang $(66,3 \%)$, responden dengan kategori berat $(7$ kali perminggu), dan responden dengan kategori diet tinggi garam yang tergolong sangat berat (lebih dari 1 kali dalam sehari) berjumlah 2 orang $(2,5 \%)$.

5. Distribusi karakteristik perilaku pasien perokok berdasarkan aktivitas olahraga yang berobat di Puskesmas Bulili Kota Palu tahun 2019

Tabel 8. Karakteristik sampel berdasarkan aktivitas olahraga

\begin{tabular}{ccc}
\hline \multicolumn{3}{c}{ Disribusi Karakteristik Sampel } \\
Berdasarkan & Aktivitas Fisik \\
\hline Aktifitas Olahraga & $\mathrm{f}$ & $(\%)$ \\
\hline Aktivitas Ringan & 53 & 66,3 \\
Aktivitas Sedang & 27 & 33,8 \\
Aktivitas Berat & 0 & 0,0 \\
\hline Total & 80 & 100 \\
\hline
\end{tabular}

Dari tabel 8 diatas dapat diketahui bahwa responden dengan aktifitas olahraga yang tergolong ringan (jarang atau tidak pernah berolahraga) sebanyak 53 orang $(66,3 \%)$, responden dengan aktivitas fisik sedang (selama kurang dari 30 menit perhari atau kurang dari 3 hari perminggu), dan responden dengan aktivitas fisik yang tergolong berat (selama lebih dari/sama dengan 30 menit perhari atau lebih dari/sama dengan 3 hari perminggu).

6. Profil hipertensi pada pasien perokok yang berobat di Puskesmas Bulili Kota Palu tahun 2019

Tabel 9. Profil hipertensi pasien perokok berdasarkan klasifikasi hipertensi menurut JNC 7

\begin{tabular}{ccc}
\hline \multicolumn{3}{c}{ Profil Hipertensi Pasien Perokok } \\
Menurut JNC 7 & \\
\hline Hipertensi & f & $(\%)$ \\
\hline Hipertensi Derajat I & 56 & 70,0 \\
Hipertensi Derajat II & 24 & 30,0 \\
\hline Total & 80 & 100 \\
\hline
\end{tabular}

Berdasarkan tabel 9 di atas menunjukkan distribusi 80 subjek penelitian yang menderita Hipertensi derajat I adalah sebanyak 56 orang (70\%) lebih besar daripada subjek yang 
menderita Hipertensi derajat II yaitu senyak 24 orang $(30 \%)$.

\section{PEMBAHASAN}

Adapun hasil dari penelitian yang dilakukan di Puskesmas Bulili Kota Palu tahun 2019.

\section{1. karakteristik perilaku pada pasien perokok} yang berobat di Puskesmas Bulili Kota Palu tahun 2019 berdasarkan frekuensi merokok.

Dari hasil penelitian terkait dengan karakteristik perilaku perokok yang menderita hipertensi di Puskesmas Bulili kota Palu tahun 2019 berdasarkan frekuensi merokok, didapati responden yang memiliki frekuensi merokok paling banyak adalah mereka yang merokok 11-20 batang perhari (perokok sedang) yaitu sebanyak 52 orang $(65 \%)$, kemudian diikuti oleh mereka yang merokok 1-10 batang perhari (perokok ringan) yaitu sebanyak 21 orang $(26,3 \%)$, angka ini lebih banyak dibandingkan mereka yang merokok >20 batang perhari (perokok berat) yang berjumlah 7 orang $(8,8 \%)$.

Berbeda dengan penelitian yang dilakukan oleh Irhamsyah A (2018) di Puskesmas Tipo yang mana didapati hasil bahwa jumlah perokok di wilayah kerja Puskesmas Tipo Kota Palu yang relatif kurang karena seringnya dilakukan penyuluhan terkait masalah rokok. Hal ini disebabkan karena penduduk di daerah Puskesmas Bulili belum mendapatkan penyuluhan yang optimal mengenai bahaya merokok dan dampak dari zat yang terdapat dalam rokok yang dapat menyebabkan meningkatnya tekanan darah sehingga dapat menimbulkan berbagai komplikasi penyakit hingga terjadinya kerusakan organ tubuh. ${ }^{15}$

Hasil dari penelitian ini sesuai dengan penelitian yang dilakukan oleh Wahyudi I (2014) dimana didapati bahwa semakin banyak jumlah rokok yang dikonsumsi maka tekanan darah dari responden juga akan semakin meningkat. Walaupun pada penelitiannya tersebut ditemukan distribusi perokok ringan dan sedang lebih dominan yaitu $40,57 \%$ dan perokok berat cenderung lebih sedikit yaitu $18,86 \%$, sehingga hal tersebut mesti dikaji lebih dalam lagi. ${ }^{16}$
Berdasarkan hal tersebut maka dapat disimpulkan bahwa karakteristik perilaku perokok berdasarkan frekuensi merokok tidak selamanya dapat menjadi pencetus dari menigkatnya tekanan darah pada pasien yang berobat di Puskesmas Bulili, karena bisa saja didasarkan pada karakteristik demografi pada populasi penelitian dan juga perlu disadari adanya faktor risiko lainnya seperti: pola makan, stress, faktor usia, riwayat keluarga dan lain-lain sehingga efek dari frekuensi merokok dalam penelitian ini belum dapat terbukti.

\section{2. karakteristik perilaku pada pasien perokok} yang berobat di Puskesmas Bulili Kota Palu tahun 2019 berdasarkan lama merokok.

Dalam hasil penelitian ini, dapat diketahui karakteristik perilaku perokok yang menderita hipertensi di Puskesmas Bulili Palu tahun 2019 berdasarkan lama merokok dimana dapat diketahui bahwa semakin lama seseorang mengkonsumsi rokok maka akan semakin tinggi tekanan darah yang dimilikinya. Pada penelitian ini didapati responden yang telah merokok selama $<5$ tahun (perokok pemula) berjumlah 7 orang $(8,8 \%)$, responden yang sudah merokok selama 5-10 tahun (perokok menengah) berjumlah 27 orang $(33,8 \%)$, serta responden yang telah merokok $>10$ tahun (perokok lama) berjumlah 46 orang $(57,5 \%)$.

Hasil ini sesuai dengan penelitian yang dilakukan oleh Wahyudi I (2014) yang mendapatkan hasil bahwa semakin lama seseorang merokok maka akan semakin berdampak terhadap peningkatan tekanan darah yang dimilikinya, kandungan zat kimia dalam rokok memiliki dose-respone effect sehingga semakin dini seseorang mengkomsumsi rokok maka akan semakin besar pengaruhnya dalam waktu yang lama sehingga dapat menimbulkan dampak dari merokok yang berbahaya seperti penyakit stroke, infark miokaridium, impotensi, kanker, dll. Hal tersebut dibuktikan dengan distribusi perilaku merokok masyarakat di wilayah kerja Puskesmas Ciputat Tanggerang Selatan yang dominan sudah merokok selama $>10$ tahun sebesar $56,61 \%{ }^{16}$ 
Jika ditinjau kembali maka sebulumnya juga telah dilakukan penelitian oleh Hasrin M, dkk (2012) yang mendapati hasil bahwa besarnya risiko perilaku merokok yang sudah lama pada seseorang memiliki makna yang besar terhadap peningkatan tekanan darahnya, hal ini dibuktikan sebanyak $47 \%$ dari responden penelitiannya menderita hipertensi karena sebelumnya telah mengkonsumsi rokok sebanyak $\geq 20$ batang/hari selama $\geq 10$ tahun, lebih banyak dibandingkan responden dengan lama merokok kategori sedang dan ringan yaitu $12,2 \% .^{17}$

Sebagai kesimpulan dalam penelitian ini dapat diketahui, bahwa risiko risiko gangguan kardiovaskuler akibat komplikasi dari hipertensi tidak hanya ditentukan dari perilaku lama merokok pada seorang perokok, melainkan juga karena frekuensi merokok yang dimilikinya.

3. Karakteristik perilaku pada pasien perokok yang berobat di Puskesmas Bulili Kota Palu tahun 2019 berdasarkan diet tinggi lemak.

Obesitas dapat menyebabkan hipertensi dan penyakit kardiovaskular. Dikarenakan diet tinggi lemak dan karbohidrat dapat meningkatkan konsentrasi norepinefrin di jaringan perifer. Hal ini menyebabkan stimulasi reseptor a1 dan b-adrenergik dapat meningkatkan aktivitas saraf simpatis. Apabila terjadi dalam jangka yang waktu lama akan meningkatkan tekanan arteri serta vasokonstriksi perifer dan menyebabkan peningkatan tekanan darah.

Pada penelitian ini didapati karakteristik responden perokok yang mengkonsumsi makanan tinggi lemak cenderung bervariasi, responden yang tergolong diet tinggi lemak kategori ringan (1-2 kali dalam seminggu) pengidap hipertensi adalah sebanyak 21 orang $(26,3 \%)$, sedangkan diet tinggi lemak kategori sedang (3-6 kali perminggu) yang mengidap hipertensi adalah sebanyak 40 orang $(50 \%)$ lebih banyak dibanding kategori diet tinggi lemak ringan dan responden dengan kategori berat (7 kali dalam seminggu) yaitu sebanyak 19 orang $(23,8 \%)$.

Sementara pada penelitian ini tidak didapati responden yang memiliki diet tinggi lemak kategori sangat berat sehingga hasil yang didapati pada penelitian ini berbeda dengan hasil yang telah didapati pada penelitian yang dilakukan Wahyudi I (2014) yang menemukan distribusi responden dengan konsumsi lemak 3-6 kali perminggu (kategori sedang) cenderung paling sedikit yaitu $17,92 \%$. Selain itu jumlah sampel yang diteliti pada penelitian ini juga berbeda dengan penelitian yang dilakukan oleh Wahyudi I (2014), yaitu sebesar 106 orang. ${ }^{16}$

Walaupun begitu hasil pada penelitian ini cukup dapat menggambarkan dampak dari diet tinggi lemak dalam waktu lama yang dapat dilihat pada perbandingan antara diet tinggi lemak kategori ringan dan diet tinggi lemak kategori sedang yang mana hal tersebut sesuai dengan penelitian yang dilakukan oleh Ekowati R (2009), yang menyatakan dalam penelitiannya bahwa seseorang yang mempunyai kelebihan berat badan lebih dari $20 \%$ dan hiperkolesterol mempunyai risiko yang lebih besar terkena hipertensi dibuktikan dengan distribusi responden diet tinggi lemak sedang sebanyak $44,1 \%{ }^{18}$

\section{Karakteristik perilaku pada pasien perokok} yang berobat di Puskesmas Bulili Kota Palu tahun 2019 berdasarkan diet tinggi garam.

Kawano (2012), dalam penelitiannya menyebutkan bahwa garam dapur merupakan faktor yang sangat berperan dalam patogenesis hipertensi. Garam dapur mengandung 40\% natrium dan $60 \%$ klorida. Garam diabsorpsi terutama di usus halus. Natrium diabsorpsi secara aktif, kemudian dibawa oleh aliran darah ke ginjal untuk disaring dan dikembalikan ke aliran darah dalam jumlah yang cukup. Garam memiliki sifat menahan cairan, sehingga mengkonsumsi garam berlebih atau makan-makanan yang diasinkan dapat menyebabkan peningkatan tekanan darah melalui sistem Renin Angiotensinogen Aldesteron. $^{19}$

Pada penelitian yang dilakukan oleh Wahyudi I (2014), masyarakat perokok yang menderita hipertensi di wilayah kerja Puskesmas Ciputat Tanggerang Selatan menunjukkan distribusi responden dengan diet tinggi garam kategori sedang lebih dominan 
daripada kategori berat dengan persentase sebesar $33,02 \%$. $^{16}$

Selaras dengan penelitian tersebut, dalam penelitian ini didapatkan hasil bahwa, responden yang mengkonsumsi makanan dengan kadar garam tinggi (sperti: mie instan, ikan asin, kecap asin, keju, ataupun saos tomat) dalam kategori 1-2 kali per minggu atau tergolong diet tinggi garam ringan adalah sebanyak 16 orang (20\%) lebih sedikit dibandingkan dengan responden diet tinggi garam kategori sedang (3-6 kali perminggu) yaitu sebanyak 53 orang $(66,3 \%)$, kebanyakan dari responden mengakui hal tersebut dengan alasan sulit untuk menghindarinya karena sudah terbiasa masak dengan menggunakan garam tanpa menyadari bahwa asupan natrium dapat menyebabkan tubuh meretensi cairan yang meningkatkan volume darah yang bisa menjadi faktor risiko dari hipertensi. Namun dalam penelitian ini didapatkan distribusi responden dalam kategori diet tinggi garam berat dan sangat berat yang cenderung masih sedikit yaitu 9 orang $(11,3 \%)$ dan 2 orang $(2,5 \%)$.

Hal tersebut dikarenakan jumlah sampel pada penelitian ini tergolong sedikit walaupun sudah dapat menggambarkan adanya pengaruh antara peningkatan tekanan darah dengan angka kejadian pada responden dengan diet tinggi garam, walaupun mesti dikaji lebih mendalam lagi.

\section{Karakteristik perilaku pada pasien perokok} yang berobat di Puskesmas Bulili Kota Palu tahun 2019 berdasarkan aktivitas olahraga.

Dalam penelitian yang dilakukan Irhamsyah A (2018), melakukan aktivitas fisik dengan intensitas sedang hingga tinggi dapat mempengaruhi tekanan darah melalui beberapa mekanisme yaitu dengan meningkatkan aktivitas sistem saraf simpatis yang diyakini sebagai penyebab tekanan darah tinggi esensial. Dalam penelitiannya dikatakan bahwa mereka dengan peningkatan kadar hormon noradrenalin menunjukkan penurunan tekanan darah yang berasal dari aktifitas fisik, dengan aktifitas fisik dapat meningkatkan aliran darah ke otak, meningkatkan pelepasan hormon growth factor atau faktor pertumbuhan dari otot rangka ke pembuluh darah, berperan dalam proses neurogenesis (perkembangan sel saraf baru atau neuron), menstimulasi angiogenesis (pembentukan sel darah baru), mempengaruhi proliferasi sel endotel dalam bentuk lapisan dalam pembuluh darah dan mempengaruhi permeabialitas endotel sel membran. ${ }^{15}$

Dalam penelitiannya, Wahyudi I (2014) menemukan bahwa responden penderita hipertensi di wilayah kerja Puskesmas Ciputat Tanggerang Selatan dominan memiliki aktivitas olahraga tergolong rendah (jarang/tidak pernah) sebesar $64,15 \% .^{16}$

Sebelumnya juga telah dilakukan penelitian oleh Hasrin M, dkk (2013) dalam penelitiannya mengenai faktor risiko kejadian hipertensi di wilayah kerja Puskesmas Bangkala Kabupaten Jeneponto yang menemukan bahwa distribusi responden dengan aktivitas fisik/olahraga yang tergolong sedang ( $<3$ kali dalam seminggu dan $<30$ menit) yaitu $21,3 \%$ dan responden dengan aktivitas fisik/olahraga yang tergolong rendah (jarang/tidak pernah) yaitu $42,7 \% .{ }^{17}$

Hasil tersebut selaras dengan hasil penelitian ini, dimana didapati distribusi responden dengan aktivitas olahraga kategori ringan (jarang atau tidak pernah) yang mengidap hipertensi sebanyak 53 orang $(66,3 \%)$ yang kemudian angka kejadiannya menurun pada responden dengan aktivitas olahraga kategori sedang ( $<30$ menit/hari atau $<3$ kali/minggu) yaitu sebanyak 27 orang $(33,8 \%)$. Namun dalam penelitian ini tidak didapati responden dengan aktifitas fisik berat, sehingga tidak didapati hasil distribusi karakteristik perilaku pasien perokok dengan aktivitas olahraga $\geq 30 \mathrm{menit} / \mathrm{hari}$ atau 3 kali/minggu. Perbedaan distribusi karakteristik responden pada penelitian bisa disebabkan karena perbedaan data demografi dari tempat penelitian atau pun karena mata pencaharian dari masyarakat di wilayah kerja puskesmas Bulili.

6. Profil hipertensi pasien perokok yang berobat di Puskesmas Bulili Kota Palu tahun 2019.

Berdasarkan hasil yang didapati dari penelitian ini, maka dapat diketahui profil 
hipertensi pada pasien perokok yang berobat di Puskesmas Bulili Kota Palu tahun 2019 dengan distribusi dari 80 orang responden didapati 56 orang $(70 \%)$ terdiagnosa mengidap hipertensi derajat 1 dan 24 orang (30\%) lainnya terdiagnosa mengidap hipertensi derajat 2.

Hasil tersebut diatas sejalan dengan penelitian yang dilakukan oleh Pande P.A (2014) dalam penelitiannya mengenai prevalensi dan faktor risiko terjadinya hipertensi pada masyarakat di desa Sidemen, Kecamatan Karangasem yang mana ditemukan distribusi penderita hipertensi derajat 1 sebanyak 26 orang (65\%) dan 14 orang (35\%) menderita hipertensi derajat 2 dari 40 orang total sampel, dalam penelitiannya ini juga ditemukan bahwa kebanyak dari responden yang menderita hipertensi memiliki riwayat merokok sebanyak 22 orang $(15,1 \%)$ dan sebanyak 18 orang $(12,3 \%)$ lainnya tidak memiliki riwayat merokok walaupun dalam penelitiannya tidak ditemukan hasil postif antara hubungan perilaku merokok dengan kejadian hipertensi pada masyarakat di desa Sidemen Kecamatan Karangasem.

Sebagai kesimpulan, pengukuran tekanan darah berdasarkan derajat hipertensi pada responden penelitian dapat berbeda-beda tergantung ketetapan klasifikasi tekanan darah yang digunakan dimana pada penelitian yang dilakukan di Puskesmas Bulili Kota Palu tahun 2019 ditemukan kebanyakan pasien perokok yang berobat menderita hipertensi derajat 1 menurut klasifikasi tekanan darah oleh JNC VII tahun 2009. ${ }^{19}$

\section{KESIMPULAN}

Berdasarkan hasil penelitian yang dilakukan pada 80 penduduk dewasa yang berobat di Puskesmas Bulili Kota Palu pada bulan Juli sampai September tahun 2019 tentang karakteristik perilaku dan profil hipertensi pada perokok, didapatkan kesimpulan sebagai berikut:

1. Karakteristik perokok penderita hipertensi yang berobat di Puskesmas Bulili Palu tahun 2019 didapatkan hasil terbanyak adalah responden yang berusia 56-65 tahun yaitu 28 orang $(35 \%)$
2. Perokok penderita hipertensi pada penelitian ini didapatkan hasil terbanyak adalah responden berjenis kelamin laki-laki yaitu 47 orang $(58,8 \%)$

3. Berdasarkan frekuensi merokok didapati hasil terbanyak adalah responden yang merokok 11-20 batang perhari yaitu sebesar 52 orang $(65 \%)$

4. Berdasarkan lama merokok didapati hasil terbanyak adalah responden yang sudah merokok selama $>10$ tahun yaitu sebanyak 46 orang $(57,5 \%)$

5. Perokok penderita hipertensi berdasarkan diet tinggi lemak didapati hasil terbanyak adalah diet tinggi lemak sedang yaitu 40 orang $(50 \%)$

6. Perokok penderita hipertensi berdasarkan diet tinggi garam didapati hasil terbanyak adalah diet tinggi garam sedang yaitu 53 orang $(66,3 \%)$

7. Perokok penderita hipertensi berdasarkan aktivitas fisik didapati hasil terbanyak adalah aktivitas fisik tergolong rendah yaitu 53 orang $(66,3 \%)$

8. Profil hipertensi perokok penderita hipertensi yang berobat di Puskesmas Bulili Palu kebanyakan mengidap hipertensi derajat 1 yaitu 56 orang (70\%)

\section{DAFTAR PUSTAKA}

1. Departemen Kesehatan RI. Hasil Riset Kesehatan Dasar. Badan Penelitian dan Pengembangan Kesehatan. Jakarta: 2010 Des 1 .

2. WHO. High Blood Pressure Global and Regiona Overview. World Health Day 2013.

3. American Heart Association, American Stroke Association. High Blood Pressure. America Heart Association Inc. All rights reserved. Unauthorized use prohibited. 2013.

4. Kementrian Kesehatan RI. Hasil Riset Kesehatan Dasar. Badan Penelitian dan Pengembangan Kesehatan. Jakarta: 2013 Des 1. P. 6-7, 139-144.

5. Yoon P W, Gollespie C D, George M G. Control of Hypertension Among AdultNational Health and Nutrition Examination Survey. MMWR . Vol 61. 2012. p. 19. 
6. Nwankwo T, Yoon S S, Burt V, et al. Hypertension Among Adults in the United States National Health and Nutrition Examination Survey. NCHS. 2013. 133 p 6.

7. Signh S, Shankar R, Signh G.P. Prevalence and Associated Risk Factors of Hypertension: A Cross-Sectional Study in Urban Varanasi. In International Journal of Hypertension. India. 2017 Des 3.

8. Sience Olympiad. 2013. Anatomy and Physiology. Sience Olympiad 1999-2013. Science Olympiad Inc. Diakses 12 Juni 2015:

http://soinc.org/anatomy_physiology_c

9. Dinas Kesehatan Provinsi Sulawesi Tengah. Data Faktor Resiko Penyakit tidak menular di Stulawesi Tengah, tahun 2016.

10. Dinas Kesehatan Kota Palu. Profil Kesehatan Kota Palu, tahun 2016.

11. Puskesmas Bulili. Data 10 Penyakit Terbesar di Puskesmas Bulili Palu, tahun 2017.

12. Centers for Disease Control and Prevention (CDC). High Blood Pressure Fact Sheet. Division for Heart Disease and Stroke Prevention. 2016 Jun 16.

13. Jamal A, Phillips E, Gentzke A.S, et.al. Morbidity and Mortality weekly Report: Current Cigarette Smoking Among Adults in United States. Centers for Disease Control and Prevention (CDC). 2018 jan 18. p. 67:53-59.

14. Asma S, Mackay J, Song YS, et.al. Global Tobacco Surveillancce System: The GATS Atlas. CDC Foundation, Atlanta. 2015.

15. Irhamsyah A. Profil Gaya Hidup dan Tekanan Darah Orang Dewasa di Wilayah Kerja Puskesmas Tipo Palu Tahun 2018. Palu: Fakultas Kedokteran Unisa Palu. 2018.

16. Wahyudi A.I. Gambaran Tekanan Darah Berdasarkan Faktor Pemberat Hipertensi pada Pasien Hipertensi Perokok di Wilayah Kerja Puskesmas Ciputat Kota Tanggerang. Jakarta: Fakultas Ilmu Keperawatan UIN Syarif Hidayatullah. 2014.

17. Mannan H, Wahiduddin, Rismayanti. Faktor Risiko Kejadian Hipertensi di Wilayah Kerja Puskesmas Bangkala
Kabupaten Jeneponto Tahun 2012. FKM Unhas. Makassar: 2013 Feb. p. 4-7.

18. Rahajeng E, Tuminah S. Prevalensi Hipertensi dan Determinannya di Indonesia. Pusat Penelitian Biomedis dan Farmasi Badan Penelitian Kesehatan Departemen Kesehatan RI. Maj Kedokt Indon. Jakarta: 2009 Des. 59(12):584. 